\title{
Estudo Comparativo entre Concentrações de Bupivacaína a $0,125 \%$ e a $0,25 \%$ Associada ao Fentanil para Analgesia de Parto por Via Peridural *
}

\section{Comparison between $0.125 \%$ and $0.25 \%$ Bupivacaine Associated to Fentanyl for Epidural Labor Analgesia}

Marcos Emanuel Wortmann Gomes ${ }^{1}$; Vanessa Rezende Balle ${ }^{2}$; Sheila Braga Machado ${ }^{3}$; Florentino Fernandes Mendes, TSA ${ }^{4}$

\section{RESUMO}

Gomes MEW, Balle VR, Machado SB, Mendes FF - Estudo Comparativo entre Concentrações de Bupivacaína a 0,125\% e a $0,25 \%$ Associada ao Fentanil para Analgesia de Parto por Via Peridural

JUSTIFICATIVA E OBJETIVOS: A analgesia de parto tem a finalidade de diminuir ou até excluir o sofrimento materno durante o trabalho de parto, sendo considerada um método seguro e efetivo para o alívio da dor. O objetivo deste trabalho foi comparar duas concentrações de bupivacaína $(0,25 \%$ e $0,125 \%$ ), associada ao fentanil na analgesia de parto por via peridural, quanto à eficácia antálgica e o grau de bloqueio motor, e verificar a influência das diferentes concentrações utilizadas na duração do trabalho de parto, no bem estar do recém-nascido e na satisfação materna.

MÉTODO: Neste estudo prospectivo e duplamente encoberto, 51 gestantes primíparas foram distribuídas aleatoriamente em dois grupos para receberem uma de duas concentrações de bupivacaína para indução de analgesia de parto $(0,25 \%$ [ $n=23]$ ou $0,125 \%$ [ $n=28]$ ). Para a mensuração da analgesia, foi utilizado a escala numérica de dor, e para a avaliação do bloqueio motor, a escala de Bromage. Para a comparação das médias, foi utilizado o teste $t$ de Student, e, para a comparação das proporções, o teste Qui-quadrado, $\operatorname{com} p<0,05$.

RESULTADOS: Não houve diferença significativa nas variáveis dor, grau de bloqueio motor e bem-estar fetal entre os dois grupos. O índice de cesariana foi significativamente maior no grupo com maior concentração $(p<0,05)$. No grupo com menor concentração, as pacientes ficaram mais satisfeitas com o procedimento $(p<0,01)$.

CONCLUSÕES: A bupivacaína na concentração de 0,125\%, associada ao fentanil, mostrou maior benefício quando comparada com a concentração de 0,25\%. Nesta dose, verificou-se menor incidência de efeitos indesejáveis sem

\footnotetext{
* Recebido da (Received from) Maternidade Mário Totta da Santa Casa de Porto Alegre, RS

1. $M E_{2}$ (2003) do CET/SBA da Santa Casa de Porto Alegre

2. Anestesiologista da Santa Casa de Porto Alegre, Mestranda em Farmacologia pela FFFCMPA, Responsável pelo Núcleo de Analgesia e Anestesia Obstétrica da Santa Casa de Porto Alegre

3. Anestesiologista da Santa Casa de Porto Alegre

4. Chefe do Serviço de Anestesiologia da Santa Casa de Porto Alegre, Mestre em Farmacologia pela FFFCMPA
}

Apresentado (Submitted) em 11 de julho de 2003

Aceito (Accepted) para publicação em 27 de outubro de 2003

Endereço para correspondência (Correspondence to)

Dra. Sheila Braga Machado

Rua Coronel Orlando Pacheco, 96

91440-050 Porto Alegre, RS

E-mail: sheilabm@santacasa.tche.br

(c) Sociedade Brasileira de Anestesiologia, 2004 comprometimento da analgesia proporcionada e maior grau de satisfação materna.

Unitermos: ANALGESIA: parto; ANALGÉSICOS, Opióides: fentanil; ANESTÉSICOS: Local: bupivacaína; TÉCNICAS ANESTÉSICAS, Regional: peridural

\section{SUMMARY}

Gomes MEW, Balle VR, Machado SB, Mendes FF - Comparison between $0.125 \%$ and $0.25 \%$ Bupivacaine Associated to Fentanyl for Epidural Labor Analgesia

BACKGROUND AND OBJECTIVES: Epidural analgesia aims at decreasing or even abolishing maternal suffering during labor. It is considered a safe and effective method for pain relief. This study aimed at comparing two bupivacaine concentrations $(0.25 \%$ and $0.125 \%)$ associated to fentanyl in epidural labor analgesia to determine its efficacy on pain relief and its effect on motor block. We have also observed the influence of these two concentrations on labor duration, fetal outcome and maternal satisfaction.

METHODS: Participated in this prospective and double blind study 51 primiparous women who were randomized to receive one out of two bupivacaine concentrations for epidural labor analgesia $(0.25 \%$ [ $n=23]$ or $0.125 \%[n=28])$. Analgesia was measured using a numeric pain scale, and motor block was verified using Bromage scale. Means were compared using Student's t test, while proportions were compared using Qui-square test, with $p<0.05$.

RESULTS: There has been no statistical difference in pain, degree of motor block and fetal outcome between groups. Cesarean delivery rate was statistically higher in the group receiving $0.25 \%$ bupivacaine $(p<0.05)$. Lower concentration group patients were more satisfied with the procedure $(p<0.01)$.

CONCLUSIONS: The association of fentanyl and $0.125 \%$ bupivacaine proved to be more beneficial as compared to $0.25 \%$ concentration. With this dose, there has been a lower incidence of adverse effects without compromising analgesia, and yet a higher rate of maternal satisfaction.

Key Words: ANALGESIA: labor; ANALGESICS, Opioids: fentanyl; ANESTHETICS, Local: bupivacaine; ANESTHETIC TECHNIQUES, Regional: epidural

\section{INTRODUÇÃO}

- m 1847 James Simpson, ao administrar éter a uma parturiente, iniciou um dos capítulos mais controversos da Medicina, a analgesia de parto ${ }^{1}$.

A partir de então, com a finalidade de diminuir ou até eliminar o sofrimento materno durante o trabalho de parto, vários métodos foram pesquisados. O objetivo de tais métodos era tornar agradável o momento do nascimento e, com isso, beneficiar a relação mãe-filho. 
Em alguns centros, cerca de $50 \%$ das gestantes se beneficiam da analgesia de parto, sendo um método considerado seguro e efetivo para o alívio da dor ${ }^{2}$.

Vários estudos foram realizados com o propósito de avaliar os efeitos da aplicação da analgesia de parto ${ }^{3,4}$. Através deles foi possível determinar e comparar técnicas anestésicas, verificando suas vantagens e desvantagens em relação a desfechos finais como, por exemplo, índice de cesariana e duração do período expulsivo. Estudos mais recentes buscam encontrar a menor dose peridural efetiva, visando uma menor incidência de efeitos deletérios ${ }^{5}$.

É muito importante que se observe o fato de que as conclusões encontradas em muitos centros de pesquisa não necessariamente se aplicam em outras instituições ${ }^{4}$. Cada hospital, e sua equipe de saúde, possui condutas práticas e vivências distintas, fazendo com que a própria indicação da cesariana, por exemplo, possa ser muito subjetiva. É difícil avaliar se a analgesia do parto aumenta a incidência de uso de fórceps ou se os obstetras se utilizam da analgesia para aplicarem o fórceps mais deliberadamente ${ }^{2}$. Portanto, cada instituição deve monitorar sua própria estatística quanto à analgesia de parto, incluindo suas diferentes técnicas, e quanto aos índices de intervenção, incluindo parto instrumentado e cesariana.

O objetivo deste trabalho foi comparar duas concentrações de bupivacaína $(0,25 \%$ e $0,125 \%)$ associada ao fentanil na analgesia de parto por via peridural, quanto à eficácia antálgica e o grau de bloqueio motor, e verificar a influência das diferentes concentrações utilizadas na duração do trabalho de parto, na vitalidade do recém-nascido e na satisfação materna.

\section{MÉTODO}

Após aprovação pelo Comitê de Ética em Pesquisa e consentimento pós-informação assinado pelas pacientes, realizou-se estudo prospectivo, encoberto e aleatório, inicialmente previsto para uma amostra de 80 gestantes atendidas na Maternidade Mário Totta da Irmandade da Santa Casa de Misericórdia de Porto Alegre. As pacientes foram selecionadas para receber um de dois tratamentos: grupo A: bupivacaína a $0,25 \%$ e fentanil $(100 \mu \mathrm{g})$ ou grupo B: bupivacaína a $0,125 \%$ e fentanil $(100 \mu \mathrm{g})$. Fizeram parte do estudo somente 51 pacientes, 23 no grupo A e 28 no grupo B, uma vez que o estudo foi interrompido com concordância do Comitê de Ética em Pesquisa, por conta de os resultados obtidos, até então, evidenciarem vantagem de um dos grupos.

Foram considerados critérios de inclusão: a) consentimento pós-informação assinado pela paciente permitindo a realização do procedimento (ou do responsável quando menor de 18 anos); b) gestantes primíparas com classificação de estado físico ASA II, com idades entre 15 e 40 anos; c) pacientes no período ativo da fase de dilatação uterina, com dilatação cervical de até $7 \mathrm{~cm}$. Foram excluídas as pacientes que apresentassem contra-indicação à realização de bloqueio peridural.
As pacientes que preencheram os critérios de inclusão e exclusão descritos foram distribuídas, aleatoriamente, através de um sorteio em que se colocou 80 papéis dentro de um recipiente - a metade com a letra $A$ e a outra metade com a letra B correspondendo aos grupos $\mathrm{A}$ ou $\mathrm{B}$, respectivamente.

Para conferir ao estudo a qualidade de encoberto, utilizou-se a seguinte técnica: após anamnese e exame físico, o pesquisador 1 realizava o sorteio do grupo ao qual a paciente pertenceria, anotava em ficha específica somente por ele conhecida, e preparava a solução analgésica a ser administrada pelo pesquisador 2 , que desconhecia as medicações utilizadas na analgesia de parto. O pesquisador 2 efetuava venóclise com cateter venoso $20 \mathrm{G}$ e monitorizava a paciente. Após isso, realizava punção lombar em $\mathrm{L}_{3}-\mathrm{L}_{4}$ com agulha Tuohy $16 \mathrm{G}$ até identificar o espaço peridural por perda de resistência. Após aspiração para certificar-se de ausência de refluxo de sangue (punção vascular acidental) ou perfuração da dura-máter, administrava-se $8 \mathrm{ml}$ da solução preparada e procedia-se a passagem do cateter peridural até a sua marca 3 na pele.

Foram administradas doses complementares de bupivacaína a $0,125 \%$ ( $3 \mathrm{ml})$, em ambos os grupos, sempre que a gestante referisse dor maior do que 6 na escala numérica de dor (questionada pelo pesquisador 2) e tivessem decorridos mais do que 10 minutos de intervalo da dose anterior.

A coleta de dados foi realizada pelo pesquisador 2 (encoberto) e os dados anotados em ficha específica. A verificação da intensidade de dor foi medida através da escala numérica de dor, ou seja, uma régua de 0 a 10 foi mostrada à paciente, que apontava o local equivalente à dor. O ponto marcado então representava um número. A verificação do grau de bloqueio motor foi realizada através da escala de Bromage modificada $(0=$ levanta os membros inferiores, $1=$ flexiona os joelhos, 2 = flexiona os tornozelos, 3 = não mexe os membros inferiores). Ambas as variáveis (dor e bloqueio motor) foram medidas após 10 minutos de cada dose peridural.

A evolução do trabalho de parto foi avaliada através da verificação da dilatação uterina e do plano da apresentação, conforme rotina obstétrica. Como medida da vitalidade fetal, utilizou-se o índice de Apgar no $1^{\circ}$ e $5^{\circ}$ minutos, fornecidos pelo pediatra. O grau de satisfação das pacientes foi obtido através de pergunta direta com as seguintes alternativas: muito satisfeita, satisfeita, indiferente, insatisfeita e muito insatisfeita.

Para a comparação das médias foi utilizado o teste $t$ de Student, e para a comparação das proporções, o teste Qui-quadrado, com $p<0,05$.

\section{RESULTADOS}

Os grupos $A$ e $B$ foram semelhantes no que concerne às características como idade, raça, prevalência de comorbidades, dilatação cervical, apresentação inicial e uso de ocitocina. Não houve diferença significativa entre os grupos nas variáveis dor, após a primeira dose da solução anestésica, número de injeções realizadas através do cateter e vitalidade fetal (Tabela I). Todas as pacientes não apresentaram ne- 
Tabela I - Dor após a Primeira Dose do Anestésico, Número de Injeções Via Cateter Peridural por Paciente, Duração do Período Expulsivo e Índice de Apgar dos Recém-Nascidos

\begin{tabular}{lcccc}
\hline & $\begin{array}{c}\text { Dor após a } \\
1^{a} \text { dose }\end{array}$ & $\begin{array}{c}\text { Número de } \\
\text { Injeções/paciente* }\end{array}$ & $\begin{array}{c}\text { Período } \\
\text { Expulsivo (min) }\end{array}$ & $\begin{array}{c}\text { Apgar 10 } \\
\text { min }^{* *}\end{array}$ \\
\hline Grupo A & $3,00 \pm 2,50$ & $0,87 \pm 1,22$ & $27,27 \pm 21,91$ & 8 \\
Grupo B & $3,29 \pm 2,55$ & $0,79 \pm 0,96$ & $13,86 \pm 7,73$ & 9 \\
\hline
\end{tabular}

* Valores expressos pela Média \pm DP

** Valores expressos pela Mediana

nhum grau de bloqueio motor. Apesar de não ocorrer diferença significativa na duração do trabalho de parto, verificou-se uma diminuição do período expulsivo no grupo com a menor concentração de bupivacaína para indução da analgesia (Tabela I). No grupo B as pacientes demonstraram maior grau de satisfação com o procedimento ( $p<0,01)$, como mostrado na tabela II. A tabela III mostra que a incidência de cesariana foi significativamente maior no grupo $A(p<0,05)$. Cruzando as variáveis satisfação e ocorrência de cesariana, verificou-se que $67,7 \%$ das pacientes muito satisfeitas tiveram parto normal (Tabela IV).

Tabela II - Satisfação das Pacientes

\begin{tabular}{lccc}
\hline Satisfação & Grupo A & Grupo B & Total \\
\hline Muito Satisfeita & $11(47,8 \%)$ & $23(82,1 \%)$ & 34 \\
Satisfeita & $12(52,2 \%)$ & $05(17,9 \%)$ & 17 \\
Total & 23 & 28 & 51 \\
\hline
\end{tabular}

Tabela III - Incidência de Cesariana

\begin{tabular}{lccc}
\hline Cesariana & Grupo A & Grupo B & Total \\
\hline Sim & $12(63,1 \%)$ & $7(36,9 \%)$ & 19 \\
Não & $11(34,3 \%)$ & $21(65,7 \%)$ & 32 \\
Total & 23 & 28 & 51 \\
\hline
\end{tabular}

Tabela IV - Satisfação das Pacientes conforme o Tipo de Parto

\begin{tabular}{|c|c|c|c|c|}
\hline & & \multicolumn{2}{|c|}{ Cesariana } & \multirow[t]{2}{*}{ Total } \\
\hline & & Sim & Não & \\
\hline \multirow[t]{2}{*}{ Satisfação } & Muito satisfeita & $11(32,3 \%)$ & $23(67,7 \%)$ & 34 \\
\hline & Satisfeita & $8(47 \%)$ & $9(53 \%)$ & 17 \\
\hline Total & & 19 & 32 & 51 \\
\hline
\end{tabular}

\section{DISCUSSÃO}

A comunidade científica preconiza como um delineamento ideal o estudo aleatório, prospectivo, duplamente encoberto e controlado por placebo. Infelizmente, em analgesia obstétrica, poucos satisfazem este padrão. Assim, não é surpresa que os vários artigos de revisão e meta-análise que tentaram evidenciar os benefícios da analgesia em relação às possíveis desvantagens foram conclusivos ${ }^{1,2,6}$. O presente estudo obedeceu aos critérios descritos, exceto pela ausência de grupo controle, visto que seria uma conduta antiética não fornecer tratamento a uma paciente que tenha recebido indicação para tal.

O surgimento de ensaios clínicos aleatórios tem ajudado a confirmar a impressão clínica de anestesiologistas e de obstetras de que a analgesia peridural pouco influencia na duração do parto e não aumenta o risco de cesariana ${ }^{1}$.

Em 1993, Eugênio e col. publicaram os resultados da utilização de analgesia de parto em quase 30 mil pacientes. Eles utilizaram bupivacaína a 0,25\% com adrenalina 1:200.000 sem opióide, por via peridural com um volume inicial de 6 a 8 $\mathrm{ml}$ ( 0 a $7 \mathrm{~cm}$ de dilatação cervical) ou 12 a $14 \mathrm{ml}$ ( 8 a $10 \mathrm{~cm}$ de dilatação cervical), administrando doses complementares, conforme ressurgimento de dor. Concluíram que esta técnica proporcionou conforto à gestante, com rápido e completo alívio da dor, não interferindo nas funções respiratórias e cardiovasculares maternas, respeitando a fisiologia do parto e não impedindo a colaboração materna no período expulsivo ${ }^{3}$. Neste estudo, utilizou-se esta mesma concentração de bupivacaína, porém foram comparados seus efeitos com os observados empregando a concentração de 0,125\%. Não foi encontrada diferença na qualidade da analgesia e no bloqueio motor quando comparadas estas duas concentrações. Parker, em estudo retrospectivo, verificou os desfechos das técnicas analgésicas, utilizando três concentrações distintas: bupivacaína a $0,375 \%$, a $0,25 \%$ e a $0,125 \%$. Aincidência de complicações como distocia, cesariana e parto instrumentado foi menor no grupo com a menor concentração $(0,125 \%)^{7}$. Em estudo prospectivo, Olofsson e col. encontraram resultados semelhantes com a bupivacaína a $0,125 \%$ associada ao sufentanil comparada à concentração de $0,25 \%{ }^{5}$. Em nosso estudo não foram encontradas diferenças entre bupivacaína a $0,25 \%$ e a $0,125 \%$ no que concerne à instrumentação do parto e alívio da dor. Entretanto, observou-se maior índice de cesariana no grupo com a maior concentração de bupivacaína.

É interessante ressaltar que as gestantes que receberam a menor concentração do anestésico ficaram mais satisfeitas do que as do grupo com maior concentração. Como a analgesia foi semelhante, pode-se deduzir que, neste estudo, a dor, isoladamente, não é o principal determinante da satisfação materna. Além disso, verificou-se que $67,7 \%$ das pacientes muito satisfeitas tiveram parto normal. Talvez essas pacientes sintam-se mais realizadas com este desfecho, uma vez que há expectativas envolvidas durante o trabalho de parto, e o parto em si poderia ser considerado a "coroação" dos esforços empreendidos durante a espera. 
Hoje, a analgesia de parto permanece um tema controverso, principalmente quanto ao paradigma de prolongar o trabalho de parto ou aumentar o índice de cesarianas, o que parece não ser verdade ${ }^{8}$. Estudos nessa área apresentam uma dificuldade básica no método. Tratam-se de estudos retrospectivos que comparam pacientes que solicitaram analgesia com aquelas que não o fizeram. Isto gera um viés de seleção que compromete os resultados e, por conseguinte, as conclusões, ou seja, as características das pacientes que escoIheram a analgesia de parto (medo da dor, por exemplo) podem também predispô-las ao desfecho final analisado (tempo prolongado de período expulsivo, por exemplo), fazendo com que a intervenção realizada nesse grupo (analgesia), na verdade, não seja responsável pelos efeitos finais.

Nas condições deste estudo a analgesia de parto por via peridural parece ter apresentado maior benefício quando foi utilizada bupivacaína na concentração de $0,125 \%$ associada ao fentanil. Nesta concentração, verificou-se menor incidência de efeitos indesejáveis, sem comprometimento da analgesia proporcionada, que se mostrou efetiva e segura. Após a realização deste estudo a concentração de bupivacaína a $0,125 \%$ associada ao fentanil passou a ser a escolha para a analgesia de parto por via peridural em nosso serviço.

\section{Comparison between $0.125 \%$ and $0.25 \%$ Bupivacaine Associated to Fentanyl for Epidural Labor Analgesia}

Marcos Emanuel Wortmann Gomes, M.D.; Vanessa Rezende Balle, M.D.; Sheila Braga Machado, M.D.; Florentino Fernandes Mendes, TSA, M.D.

\section{INTRODUCTION}

When James Simpson administered ether to a parturient in 1847 , he has started one of the most controversial chapters of Medicine, labor analgesia ${ }^{1}$.

From then on, several methods have been investigated to make pleasant the moment of birth and, with this, to benefit mother/child relationship.

In some centers, approximately $50 \%$ of parturients benefit from labor analgesia, which is a safe and effective method for pain relief ${ }^{2}$.

Several studies were conducted aiming at evaluating the effects of labor analgesia ${ }^{3,4}$. They have allowed for comparing anesthetic techniques evaluating their advantages and disadvantages in terms of final outcomes such as C-section index and expulsion period duration. More recent studies are trying to find the lowest effective epidural dose aiming at a lower incidence of adverse events ${ }^{5}$.

It is important to recognize that conclusions reached by several research centers are not necessarily applied to other institutions ${ }^{4}$. Each hospital and its healthcare team has different practical approaches and experiences making the indica- tion itself of C-section, for example, very subjective. It is difficult to evaluate whether labor analgesia increases the incidence of forceps or whether obstetricians use analgesia to more deliberate apply forceps ${ }^{2}$. So, each institution should monitor its own statistics about labor analgesia, including different techniques, and about intervention rates, including instrumented labor and C-section.

This study aimed at comparing two bupivacaine concentrations $(0.25 \%$ and $0.125 \%)$ associated to fentanyl for epidural labor analgesia in terms of pain relief and degree of motor block, and at observing the influence of different concentrations in labor duration, neonate vitality and maternal satisfaction.

\section{METHODS}

After the Research Ethics Committee approval and their informed and written consent, a prospective, blind and randomized study was carried out initially considering a sample of 80 patients from Maternidade Mario Totta, Irmandade da Santa Casa de Misericórdia, Porto Alegre. Patients were randomized to receive one out of two treatments: group A - $0.25 \%$ bupivacaine and fentanyl $(100 \mu \mathrm{g})$ or group B - $0.125 \%$ bupivacaine and fentanyl $(100 \mu \mathrm{g})$. Only 51 patients participated in the study: 23 in group $A$ and 28 in group $B$, since the study was interrupted with agreement of the Research Ethics Committee because results obtained to date had already evidenced advantages for one group.

Inclusion criteria were: a) informed and written consent of patient (or tutor if patient was less than 18 years old); b) primiparous patients, physical status ASA II, aged 15 and 40 years; c) patients in active uterine dilatation with cervical dilatation of up to $7 \mathrm{~cm}$.

Exclusion criteria were counterindications to epidural block. Patients fulfilling inclusion and exclusion criteria were randomly distributed through a drawing in which 80 pieces of paper were placed within a container - half with letter $A$ and half with letter B - corresponding to groups Aor B, respectively.

The following technique was used to obtain a blind study: after history and physical evaluation, investigator 1 would draw to group the patient would belong to, would record it on a specific file only known by him, and would prepare the analgesic solution to be administered by investigator 2 , who was blind to drugs used for labor analgesia. Investigator 2 would perform venoclysis with $20 \mathrm{G}$ venous catheter and would monitor patient. Then, lumbar puncture with Tuohy $16 \mathrm{G}$ needle was performed in $L_{3}-L_{4}$ until epidural space identification by loss of resistance. After aspiration to be sure of the absence of blood reflux (accidental vascular puncture) or dural perforation, 8 $\mathrm{mL}$ of the prepared solution was administered and epidural catheter was inserted until its mark 3 at skin.

Additional $0.125 \%$ bupivacaine doses $(3 \mathrm{~mL}$ ) were administered in both groups, whenever patients referred pain higher than 6 in pain numeric scale (asked by investigator 2) and more than 10 minutes after the previous dose.

Data were collected by investigator 2 (blind) and recorded on specific files. Pain intensity was measured by pain numeric 
scale, that is, a ruler from 0 to 10 was shown to patient who would point to the site equivalent to pain. This point represented a number. Motor block degree was measured by modified Bromage's scale ( 0 = raises lower limbs; 1 = bend knees; 2 = bend ankles; 3 = does not move lower limbs). Both variables (pain and motor block) were measured 10 minutes after each epidural dose.

Labor evolution was evaluated by uterine dilatation and presentation plane, according to obstetric routine. Fetal vitality was evaluated by Apgar score in the $1^{\text {st }}$ and $5^{\text {th }}$ minute and supplied by the pediatrician. Patients satisfaction was obtained by direct question with the following alternatives: very happy, happy, indifferent, unhappy and very unhappy.

Student's $t$ test was used to compare means and Chi-square test was used to compare proportions, with $p<0.05$.

\section{RESULTS}

Groups A and B were similar in age, race, prevalence of co-morbidity, cervical dilatation initial presentation and use of oxytocin. There has been no significant difference between groups in pain variables after the first anesthetic solution dose, in number of injections via catheter and fetal vitality (Table I). There has been no motor block for all patients. Although without statistically significant differences in labor, there has been a decrease in expulsion period in the group receiving the lower bupivacaine dose (Table I). Group B patients were happier with the procedure $(p<0.01)$, as shown in table II. Table III shows that the incidence of $\mathrm{C}$-sections has been significantly higher in group $A(p<0.05)$. Crossing satisfaction and $\mathrm{C}$-section variables, it has been observed that $67.7 \%$ of very happy patients had vaginal delivery (Table IV).

Table II - Patients' Satisfaction

\begin{tabular}{lccc}
\hline Satisfaction & Group A & Group B & Total \\
\hline Very Happy & $11(47.8 \%)$ & $23(82.1 \%)$ & 34 \\
Happy & $12(52.2 \%)$ & $05(17.9 \%)$ & 17 \\
Total & 23 & 28 & 51 \\
\hline
\end{tabular}

Table III - Incidence of C-section

\begin{tabular}{lccc}
\hline C-section & Group A & Group B & Total \\
\hline Yes & $12(63.1 \%)$ & $7(36.9 \%)$ & 19 \\
No & $11(34.3 \%)$ & $21(65.7 \%)$ & 32 \\
Total & 23 & 28 & 51 \\
\hline
\end{tabular}

Table IV - Patients' Satisfaction according to Type of Delivery

\begin{tabular}{|c|c|c|c|c|}
\hline & & \multicolumn{2}{|c|}{ C-section } & \multirow[t]{2}{*}{ Total } \\
\hline & & Yes & No & \\
\hline \multirow[t]{2}{*}{ Satisfaction } & Very happy & $11(32.3 \%)$ & $23(67.7 \%)$ & 34 \\
\hline & Happy & $8(47 \%)$ & $9(53 \%)$ & 17 \\
\hline Total & & 19 & 32 & 51 \\
\hline
\end{tabular}

\section{DISCUSSION}

An ideal design for the scientific community is a randomized, prospective, double blind, placebo-controlled study. Unfortunately, few studies in obstetric analgesia satisfy this standard. So, it is not surprising that several review and meta-analysis studies trying to evidence the benefits of analgesia as compared to possible disadvantages were not conclusive ${ }^{1,2,6}$. Our study has followed the above criteria, except for the absence of a control group, since it would be anti-ethic not to treat a patient indicated for such.

Randomized clinical trials have helped confirming the clinical impression of anesthesiologists and obstetricians that epidural analgesia poorly influences labor duration and does not increase the risk for $\mathrm{C}$-section ${ }^{1}$.

In 1993, Eugênio et al. have published the results of labor analgesia in almost 30 thousand patients. They have used $0.25 \%$ epidural bupivacaine with 1:200,000 epinephrine without opioids with an initial volume of 6 to $8 \mathrm{~mL}$ ( 0 to $7 \mathrm{~cm}$ of cervical dilatation) or 12 to $14 \mathrm{~mL}$ (8 to $10 \mathrm{~cm}$ of cervical dilatation) and administering additional doses, according to pain. They have concluded that this technique has provided comfort to patients with fast and complete pain relief and not interfering in maternal respiratory and cardiovascular functions, respecting labor physiology and not preventing maternal cooperation during expulsion ${ }^{3}$. In this study, with this same bupivacaine concentration, its effects have been compared to $0.125 \%$ concentration. There has been no difference in analgesia quality and motor block when both concentrations were compared.

In a retrospective study, Parker has observed the outcomes of analgesic techniques using three different concentrations: $0.375 \%, 0.25 \%$ and $0.125 \%$ bupivacaine. The incidence of complications, such as dystocia, C-section and instrumented delivery has been lower in the group with the lower concentration $(0.125 \%)^{7}$. In a prospective study, Olofsson et al. have found similar results with $0.125 \%$ bupivacaine asso-

Table I - Pain after First Anesthetic Dose, Number of Injections via Epidural Catheter per Patient, Expulsion Period Duration and Neonates Apgar Score

\begin{tabular}{lccccc}
\hline & Pain after the $1^{\text {st }}$ dose * & $\begin{array}{c}\text { Number of injections/pa- Expulsion Period (min) } \\
\text { tient }\end{array}$ & $\begin{array}{c}\text { Apgar } 1^{\text {st }} \\
\text { min ** }\end{array}$ & $\begin{array}{c}\text { Apgar } 5^{\text {th }} \\
\text { min ** }\end{array}$ & 8 \\
\hline Group A & $3.00 \pm 2.50$ & $0.87 \pm 1.22$ & $27.27 \pm 21.91$ & 9 \\
Group B & $3.29 \pm 2.55$ & $0.79 \pm 0.96$ & $13.86 \pm 7.73$ & 8 \\
\hline
\end{tabular}

* Values in Mean \pm SD

** Values expressed by Median 
ciated to sufentanil, as compared to $0.25 \%$ concentration ${ }^{5}$. There have been no differences in our study between $0.25 \%$ and $0.125 \%$ bupivacaine in terms of instrumented delivery and pain relief. There has been, however, a higher incidence of $\mathrm{C}$-sections in the higher concentration group.

It is worth highlighting that parturients receiving the lower anesthetic dose were happier as compared with the higher concentration group. Since there has been similar analgesia, one may conclude from this study that pain alone is not the major determinant for maternal satisfaction. In addition, it has been observed that $67.7 \%$ of very happy patients had vaginal delivery. It is possible that they have felt more realized with this outcome, since there are expectations during labor, and delivery itself could be considered the "crowning" of efforts during wait.

Today, labor analgesia remains a controversial subject, especially in terms of paradigm to prolong labor or increase the number of C-sections, which does not seem to be true ${ }^{8}$. Studies in this area have a basic methodological difficulty. These are retrospective studies comparing patients asking for analgesia to those not asking. This generates a selection bias compromising results and, as a consequence, conclusions, that is, characteristics of patients choosing labor analgesia (fear of pain, for example) may also predispose them to the analyzed final outcome (prolonged expulsion period, for example), not making interventions in this group (analgesia) responsible for final effects.

In the conditions of this study, epidural labor analgesia seems to have been more beneficial with $0.125 \%$ bupivacaine associated to fentanyl. There has been a lower incidence of undesirable effects without compromising analgesia, which has shown to be effective and safe. After this study, $0.125 \%$ bupivacaine associated to fentanyl has become the concentration of choice for epidural labor analgesia in our center.

\section{REFERÊNCIAS - REFERENCES}

01. Segal S - The effect of epidural analgesia on the progress and outcome of labor and delivery: why are we still discussing the question? IARS Review Course Lectures, 2000;73-77.

02. Zhang J, Klebanoff M, DerSimonian R - Epidural analgesia in association with duration of labor and mode of delivery: a quantitative review. Am J Obstet Gynecol, 1999;180:970-977.

03. Eugênio AGB, Cavalcanti FS - Analgesia de parto condutiva anestésicos e outras drogas. Rev Bras Anestesiol, 1993;43: 57-63.
04. Thorp J - Epidural analgesia for labor: effect on the cesarean birth rate. Clin Obstet Gynecol, 1998;41:449-460.

05. Olofsson A-Obstetric outcome following epidural analgesia with bupivacaine - adrenaline $0.25 \%$ or bupivacaine $0.125 \%$ with sufentanil: a prospective randomised controlled study in 1,000 parturients. Acta Anaesthesiol Scand, 1997;41:1-9.

06. Thorp J - Does epidural analgesic technique influence mode of delivery? Acta Anaesthesiol Scand, 1998;42:281-283.

07. Parker RK - Influence of labor epidural management on outcome in obstetrics. Reg Anesth, 1992;17:(Suppl):31.

08. Impey L, MacQuillan K, Robson M - Epidural analgesia need not increase operative delivery rates. Am J Obstet Gynecol, 2000;182:358-363.

\section{RESUMEN}

Gomes MEW, Balle VR, Machado SB, Mendes FF - Estudio Comparativo entre Concentraciones de Bupivacaína a 0,125\% y a $0,25 \%$ Asociada al Fentanil para Analgesia de Parto por Vía Peridural

JUSTIFICATIVA Y OBJETIVOS: La analgesia de parto tiene la finalidad de disminuir, o hasta excluir el sufrimiento materno durante el trabajo de parto, siendo considerada un método seguro y efectivo para el alivio del dolor. El objetivo de este trabajo fue comparar dos concentraciones de bupivacaína $(0,25 \%$ e $0,125 \%)$, asociada al fentanil en la analgesia de parto por vía peridural, cuanto a la eficacia antálgica y el grado de bloqueo motor, y verificar la influencia de las diferentes concentraciones utilizadas en la duración del trabajo de parto, en el bien estar del recién-nacido y en la satisfacción materna.

MÉTODO: En este estudio prospectivo y duplamente encubierto, 51 gestantes primíparas fueron distribuidas aleatoriamente en dos grupos para recibir una de dos concentraciones de bupivacaína para inducción de analgesia de parto $(0,25 \%$ [ $n=23]$ ó $0,125 \%$ [ $n=28]$ ). Para la mensuración de la analgesia, fue utilizada la escala numérica de dolor, y para la evaluación del bloqueo motor, la escala de Bromage. Para la comparación de las medias, fue utilizado el teste $t$ de Student, y, para la comparación de las proporciones, el teste Qui-cuadrado, con $p<0,05$.

RESULTADOS: No hubo diferencia significativa en las variables dolor, grado de bloqueo motor y bienestar fetal entre los dos grupos. El índice de cesárea fue significativamente mayor en el grupo con mayor concentración $(p<0,05)$. En el grupo con menor concentración, las pacientes quedaron más satisfechas con el procedimiento $(p<0,01)$.

CONCLUSIONES: La bupivacaína en la concentración de $0,125 \%$, asociada al fentanil, mostró mayor beneficio cuando comparada con la concentración de 0,25\%. En esta dosis, se confirmó menor incidencia de efectos indeseables sin comprometimiento de la analgesia proporcionada y mayor grado de satisfacción materna. 